\title{
Guns versus Butter: An Analysis of the Impact of Military Spending on Economic Growth in a Low- income Country: A Case of Uganda 1970-2018
}

james mukoki ( $\nabla$ jammy.mukoki@gmail.com )

Makerere University College of Business and Management Sciences https://orcid.org/0000-0002-30437479

John B Oryema

Makerere University

James Wokadala

Makerere University

Research

Keywords: Economic growth, defense expenditure, Uganda, long time series

Posted Date: June 30th, 2021

DOI: https://doi.org/10.21203/rs.3.rs-637930/v1

License: (c) (i) This work is licensed under a Creative Commons Attribution 4.0 International License. Read Full License 


\title{
Guns versus Butter: An analysis of the impact of military spending on economic growth in a low-income country: A case of Uganda 1970-2018
}

By

James Mukoki ${ }^{1}$, John B Oryema ${ }^{2}$ and James Wokadala ${ }^{3}$

\begin{abstract}
Background: As part of public expenditure, empirical studies on the impact of military/defense expenditure on the economic growth, particularly in the case of a developing country like Uganda remain still abstruse to both policymakers, researchers, and academicians. There is a scanty agreement in this regard today. For the case of Uganda, a country that has had a fair share of its instabilities and wars, the subject of military expenditure and national security becomes a topic of national importance. And although the country has registered some progress in economic growth, hovering at around 5\% annually, its military expenditure as a percentage of GDP has also been raising at an average of $2.5 \%$, and it is projected to continue rising if the present uncertainty in the country remains unabated. Thus, in this study, a time series model is estimated to analyze the association between military/defense expenditure (as \% of GDP) and economic growth in Uganda for the period 1970 through 2019. By employing the augmented Solow growth model parameterized through the ARDL model, we test the impact of military expenditure on economic growth in Uganda for both short and long-run scenarios.

Results: The findings are indicative that military expenditure does affect economic growth in Uganda although the effect is not significant. Also, the impact of security-related factors such as military expenditure by the neighbors, election year, and conflict type on growth rates seem to be mixed in both short and long-run scenarios. In addition the results reveal that a percentage point change in the level and first lag of military expenditure (Milex) is associated with 0.30 and 2.81 percentage point reduction in GDP growth in Uganda. A similar result is reported in (Islam, 2015; Saba and Ngepah, 2019). However, the impact of military expenditure on the economy has been uncertain depending on the role of the expenditure, for instance, according to (D'Agostino et al., 2012) military expenditure can be growth-enhancing if it is meant to create a peaceful environment for businesses to thrive but it can be detrimental if such expenditure is to finance external wars and internal conflicts, where productive resources like labor and capital are lost thus affecting growth.
\end{abstract}

Conclusion: Several take-home points emerge especially on public expenditure regarding the military versus other productive sectors. For instance governments in developing countries should keenly watch over their respective defense budgets and should thus allocate financial resources in tandem with both internal and external threats to the national security of their countries but also in line with resources allocated to other productive investment sectors like health, education and food productivity, such as agricultural sector in case of Uganda which seem to have direct multiplier growth effects. Besides reduction in military expenditure will avoid the crowding-out effect of productive private investment by government. For the case of Uganda, if such alarming defense expenditures are left unabated, Uganda's previously registered rates of growth may either stagnate or even deteriorate. Thus an urgent solution is needed.

JEL Code: $\mathrm{E62} \& \mathrm{H5}$

Keywords: Economic growth, defense expenditure, Uganda, long time series

\footnotetext{
${ }^{1}$ Mukoki James is a PhD student at Makerere University/ jammy.mukoki@gmail.com

2 John B Oryema (PhD) is a senior Lecturer at school of Economics, Makerere University/ jboryema@gmail.com

${ }^{3}$ James Wokadala (PhD) is senior Lecturer \& Dean- School of Statistics, Makerere University. Kampala, Uganda
} 


\section{Introduction}

For over two decades, (1966-1986) the period following Uganda's declaration of independence, the country witnessed the darkest days in its political and economic history because of the internal jostling for political power based on the diverse tribal lines (Omitoogun, 2003). The military took the center stage in long-drawn shoving for power. Since the end of the crisis periods of the early 1980s and early 2000s, military expenditure resources in Uganda has surged and received a great deal of concern from donors, civil society organizations and human right activists (Bove and Brauner, 2016; Wezeman et al., 2020). According to the Stockholm International Peace Research Institute (SIPRI), Military expenditure is defined as expenditure on both current and capital spending on the armed and peacekeeping forces, defense ministries, agencies, and departments (MDA) involved in security activities and other military spaces Kuimova, (2020). These expenditures include payments to both the military and civil servants working with the military, pensions and social security for the military retirees, operational expenses and maintenance, procurement, military R\&D, and military aid in the case of developed countries. Military expenditure is also known as a military/defense budget which refers to the number of financial resources put aside by the government to raise and maintain an armed force and other military installations (Aizenman and Glick, 2006). In this regard, there are many intriguing economic questions that economist can tease out concerning government economic expenditure but more specifically the impact of military expenditure (\% of GDP) (henceforth Milex) on macroeconomic variables such as economic growth, the balance of payments, inflation, cross border inflows and employment occupies a center stage. Spending on the military in many of the developing countries constitutes the biggest component of government spending to the extent that such expenditures exceed that on essential welfare sectors such as agriculture education and health. Such contradicting trend investment in essential sectors compared to the military may affect growth in developing countries.

Nonetheless, there has been varying views from both development and international economist around the world as regards to the contribution of Milex in the nation's economic growth and development, many believe it crowds out the competition in the private sector in terms of productive expenditure and private investment ventures (D'Agostino et al., 2012; Dunne et al., 2005; Heo, 2010; Kuimova, 2020). A pioneering study by Benoit in 1978 was among the first attempts to link military expenditure and economic growth Dunne et al., (2005), his results revealed that in the case of LDCs, military expenditure increase economic growth. This paved the way for the raise of growth-military expenditure nexus literature (Ali and Donald, 2020; Hou and Chen, 2013; Nusrate and Niaz, 2016; Temple, 1998; Wijeweera and Webb, 2012), applying modern estimation techniques, datasets, and different theoretical and empirical underpinnings, but with varying levels of results, inconsistences and controversies thus rendering this topic inevitable for further interrogation. At the global level, Milex hit its highest during the 1970s cold war period, but it has drastically decreased ever since then (Tian et al., 2018). This reduced expenditure burden is expected to yield peace dividends and thus growth for most developing countries (Wezeman et al., 2020). Despite the end of major conflicts around the world, a large number of low-income countries still spend a significant amount of their meager national resources on military activities (Ali and Donald, 2020). According to the World Development indicator report 2019, close to 13 percent of expenditures in developing countries goes on defense and military activities. The picture in Uganda is no different given the bad history characterized by conflicts, military expenditure has seen its highs and lows. For instance, the highest Milex (as \% of GDP) in Uganda since 
independence was reported in 1972 at 4.06 and the lowest was 0.11 in 1962 . According to the World Bank development indicators, Milex stood at 1.43 and 2.05 in 2018 and 2019 respectively.

Due to such increasing defense budgets in Uganda, compared to other essential welfare improving sectors such as agriculture, health, and education, the impact of defense spending on economic growth needs to be explored fully in Uganda's context. This study thus aims at first analyzing the impact of raising defense/military expenditure on economic growth in Uganda using a much longer and newer dataset is used. Secondly, following Dunne et.al (2005), we incorporate models on both defense economics and neoclassical growth theories. Lastly, we incorporate regional effects by incorporating military expenditure figures of the neighbors. Also, we analyze both the short-run and long-run effects of defense expenditure on economic growth. A common convergence among many of the empirical studies in this field has resonated on the negative effects of military expenditure on growth. One of the pioneering studies in this field was carried out by Barro in 1995 found a non-significant decreasing effect of military expenditure on growth. Such contradicting results we think may be due to biases in variable omission and non-linearity in the estimation. However, to isolate real growth effects on military expenditure on the economy, we follow Heo, (2010) and control for possibilities of external threat captured by the military expenditure budget of the neighbors, and an ADRL model is estimated.

\subsection{Research Problem}

Much of what we know presently on Uganda's military expenditure is mainly in terms of Statistical figures from mainly international development agencies (i.e., the World Bank, the IMF, and SIPRI). Such evidence suggests that government expenditure in many of the low-income countries has failed to translate into an improvement in people's welfare, more generally in economic growth (see World Bank report 2019). Much of this expenditure goes to finance the defense budgets, even though much of the time such armies are preoccupied with peace missions abroad which negate development opportunities locally. Secondly, Uganda does not manufacture any of the military soft and hardware equipment which leads to much of the capital flight witnessed in many of the countries in Africa Tian et al., (2018). On the other hand, many of the claims on the impact of military expenditure have been in developed countries where governments invest a significant proportion of their national resources on their military R\&D to enhance their military capabilities for example Israel and the USA. However, many of the empirical studies on Milex-growth nexus have found significant negative impacts for different countries with limited attention to Uganda in particular. Traditional macroeconomists believe that government expenditure stimulates spending and consumption which is welfare improving, however, this argument may be different in nonmilitary manufacturing countries like Uganda, where such expenditure may lead to capital flight. This situation has worried many development economists in that many of these low-income countries may be experiencing negative growth rates since much of their meager resources are spent abroad on military hardware. It is from this backdrop that this study is premised to examine the relationship between defense expenditure and economic growth in Uganda.

\subsection{Motivation for this study}

Although governments around the world are mandated to ensure national security and protection from external threat to ensure stability which may lead to economic development, increasing military spending can burden the economy in case of developing countries with meager resources and this may impede economic growth in the long run (Bove and Brauner, 2016). Uganda's defense budget has been on a relentless increasing trajectory since the early 1980s, surpassing 
expenditure on essential sectors such as health, education, and agriculture, this admiration for huge defense spending has been displayed by the president where he has been quoted severally "saying security first" and this momentum is projected to rise further particularly during the election period (see CEDU, CESBAG and SPIRI, 2019). Although Uganda has witnessed relatively stable rates of growth averaging 4-5\%, there has been no empirical study in Uganda in particular to model the contribution of raising Milex spending to economic growth, this motivated our study. Besides earlier studies have relied on cross-sectional estimation procedures thus failing to dynamically account for the impact of Milex on GDP growth. The main purpose of this study was to analyze the impact of military expenditure on Economic growth in a developing country context like Uganda for a period of 1970-2019.

\subsection{Research Question}

This study aimed at answering one key fundamental question: Is there a significant positive effect of military expenditure on Economic growth in a developing country like Uganda in both the short and long-run?

\subsection{Study Hypothesis}

The study tested one key research hypothesis; Ho: There is no significant effect of military expenditure on Economic growth in Uganda.

\section{An overview of Military expenditure and economic growth in Uganda}

There are two major sources of data about military spending activities in Uganda, and include, national and international sources, locally, military expenditure information about Uganda can be obtained from three distinct sources, namely the Background to the Budget and the Budget Speech from the Ministry of Finance Planning and Economic Development and Statistical Abstract (Uganda Bureau of Statistics (UBOS), 2017). And the governance finance yearbook provides international sources (Ali and Omong, 2020). Uganda's expenditure on the military in 2017 was reported at shillings 1,604,981.053 million, lower than that reported in 2016 at UGX $1,789,078.134$ million, this budget is updated yearly and the increment has averaged UGX 38,541.575 UGX millions from Jun 1962 to 2017, with 56 observations. According to the forecasts and projections sourced from the World Bank, Uganda's military expenditure as a \% of GDP was reported at 2.05 in 2019, and it's all-time highest was reported in 2016 at UGX 1,789,078.134 million and the lowest of UGX 0.052 UGX millions was reported in 1962, this data is available and reported by the World Bank Group as a collection of World Development indicators, below is a graphic indicating military expenditure in Uganda as a \% of GDP since 1962 to 2019. 


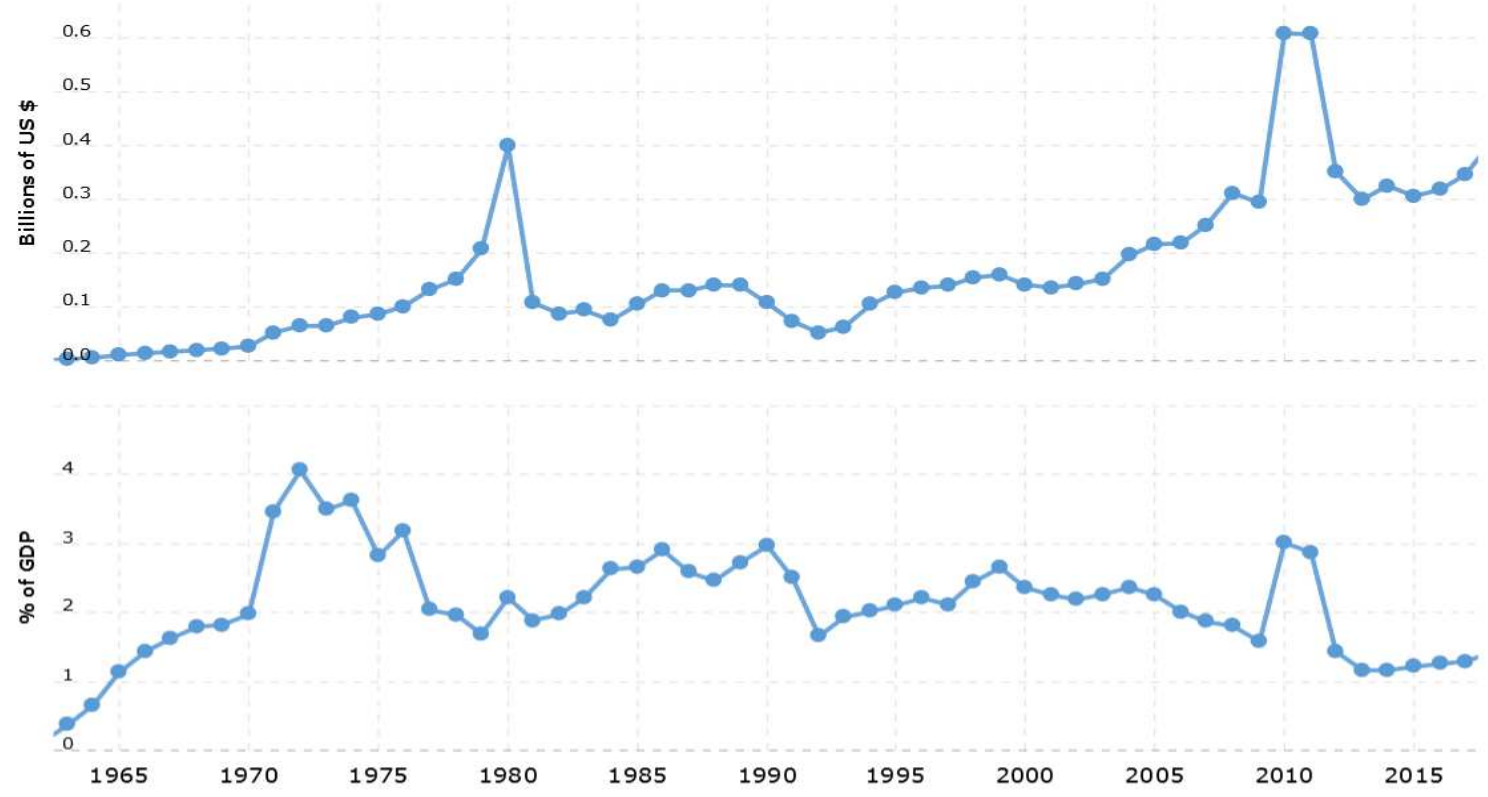

Figure 1: Uganda's Military Spending 1965-2015, Source: SPIRI and WDI

Upon assisting Uganda to fight conflicts and wars that claimed a lot of lives in the northern part of the country between the 1990s and early 2000s, development partners put a caveat on Uganda's military expenditure not to exceed $2 \%$ of annual GDP. However, according to SIPRI which is the global custodians of military expenditure information, Uganda's defense gets more than its official budget share through the numerous supplementary budgets submitted to parliaments. How much addition it gets is top secretary (Dignum et al., 2020). However, disbursement of the budgeted funds to other ministries can collaborate these claims(Ali and Omong, 2020). The results from the graphs above still support claims on military expenditure. The period in the 1970s, 1980s, and early 2000s can be seen with increased military spending as a proportion of GDP since they correspond to periods that involved civil wars and political unrests in Uganda.

According to the third National Development Plan (NDP III), Uganda has registered impressive economic growth rates for the last three decades since the return of normalcy from the insecurity times of the 80s and 90s. For instance, economic growth in 2019 was, $\$ 34.39 \mathrm{~B}$, which reflects an increase of $4.93 \%$ from 2018, $\$ 32.77 \mathrm{~B}$ for 2018 with an increase of $6.56 \%$ from $2017, \$ 30.76 \mathrm{~B}$ for 2017 with a raise of $6.18 \%, \$ 28.97 \mathrm{~B}$ for 2016 with a raise of $9.83 \%$ from 2015 , which represents the highest single increase in the last five years of growth. While the GDP growth rates for the last five years from 2019 to 2015 are $6.51 \%,(0.35 \%), 6.16 \%,(2.26 \%), 3.90 \%,(0.88 \%)$ and $4.78 \%,(0.41 \%)$, where the values in the brackets indicate either a raise or a decrease from the previous year rates (NPA, 2020). 


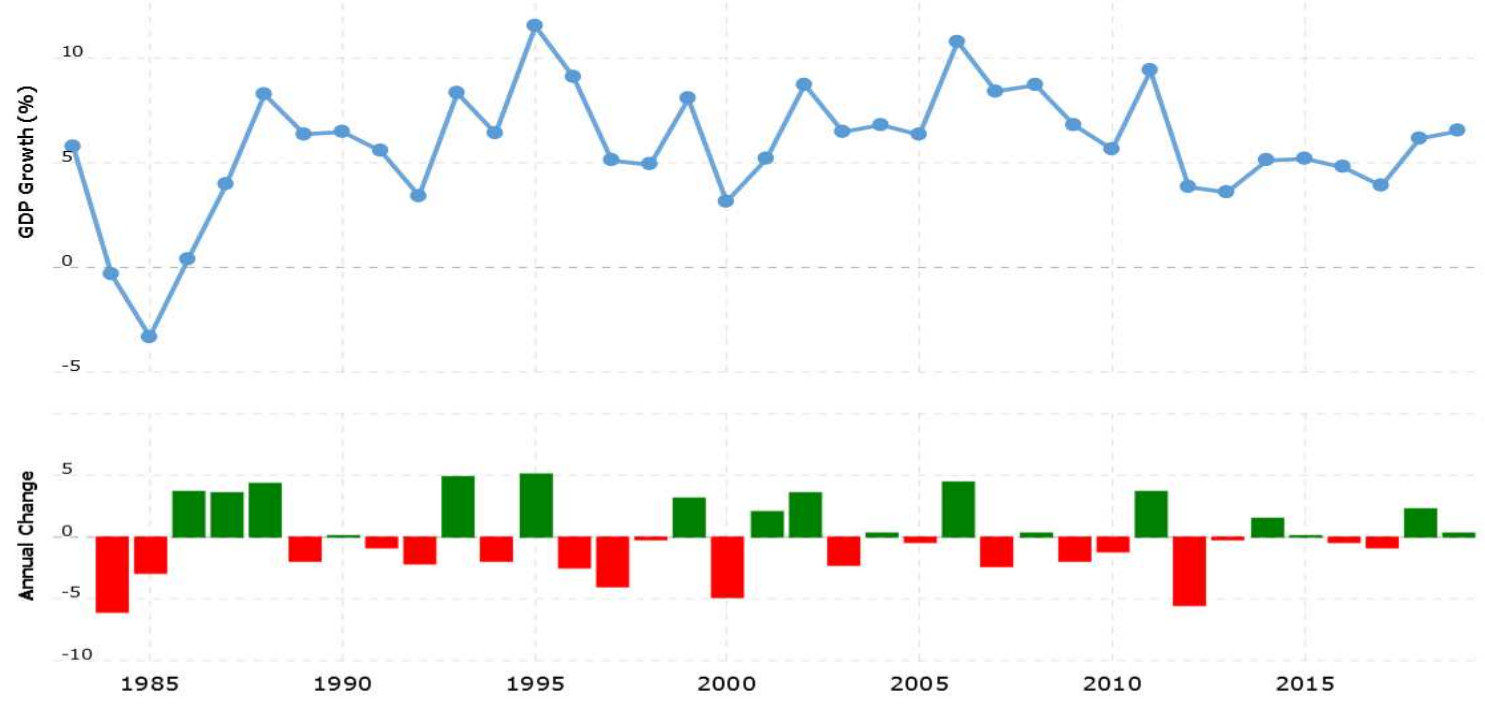

Figure 2: Annual change and GDP growth rates, source: WDI

\subsection{Economic Growth and Defense spending: a theoretical review}

Until now, all that we knew about the impact of military expenditure was from a grounding breaking study by Benoit 1978, carried out among forty-four low-income countries finding a controversial positive effect of military expenditure on government spending. Ever since then economists have applied numerous models borrowed from different fields of economics and across other fields to investigate the impacts of the growth of this type of expenditure. However, there seems to be no agreed-upon theory or even consensus among empirical researchers about the real economic impacts delivered from military expenditure (Aizenman and Glick, 2006; Dunne et al., 2005). A review of military literature and public sector spending indicates that four theoretical frameworks have dominated the study of Milex-growth nexus, first being the regression type models based on Benoit (1978), second, being models based on supply-side argument also known as Feder-type models, thirdly is demand-side models, the fourth category combines demand and supply arguments and lastly the traditional Solow growth models (D'Agostino et al., 2012; Dunne et al., 2005)

According to Dunne et al., (2005), military expenditure can affect output or economic growth through three major channels, namely; through the demand, supply, and finally security effects. Under demand effects, there are two forces which are both positive and negative. On the positive side, increased military expenditure leads to increased consumption and use of resources and reduce consumption. However, this raise in military expenditure may crowd out another important spending on other vital sectors such as health. Financing an increased defense budget may require external borrowing, cuts in other sectors, increased taxes, and printing of more money which may affect the monetary policy of the country (Omitoogun, 2003). On the supply side, the effects of military expenditure on economic growth are realized through the Supply of factors of production. From the traditional production function, these factors include labor, human $\&$ physical capital, natural resources, and also the level of technology. Lastly, security effects operate through the protection of peoples' lives and their productive properties from external threat, ensuring security is also essential for stability of markets, investment and innovation, i.e. increase in military expenditure is expected to raise output due to the creation of an ambiance environmental suitable 
for productivity. However, in case of wars with the neighbors then increased military expenditure may decrease output (D’Agostino et al., 2012).

Nonetheless, these earlier attempts on the theorization of the concept of military expenditure have been criticized on several grounds, for instance, theoretical arguments from Benoit's study are a special case that cannot be replicated in the scientific literature (D'Agostino et al., 2012; Dunne et al., 2005). The failure to account for supply-side factors in the modeling is the main reprimand labeled against the demand-side models and this is said to cause negative effects on economic growth. The Feder-Ram model' on the other hand has been criticized on both theoretical and econometric grounds (Dunne et al. 2005). The Deger models are blamed for lacking a strong theoretical basis is in their specification, similarly, the Barro growth models have been condemned for their complexity in their estimation and according to Dunne et al. (2005), and such models are only applied to obtain study variables. A survey of studies on the impact of military expenditure on economic growth gives a mixed bag of results, for example, some give a positive, negative, or even non-significant effects of military expenditure on growth. For instance, considering the above theoretical review, non-significantly positive effects have been reported in Feder type models, while negative effects have been reported in both the demand side models and Deger-type models (Looney, 1988). Therefore the inclusion of a theoretical model adopted in the study of military expenditure on economic growth greatly drives the empirical results (Temple, 1998). Based on the above-synthesized literature on public expenditure, this study is based on (Knight et al. 1996 cited in Dunne et al., 2005) extended Augmented Solow growth models. In this framework, Knight and others incorporate the impact of military expenditure into the standard Neoclassical Solow growth model. Some studies have tested this framework using variables such as security threat, neighbor's military spending, and results have turned out either positive or negative (Heo, 2010; Kuimova, 2020; Nonneman and Vanhoudt, 2011; Temple, 1998).

\subsection{Literature review}

There is a host of growing empirical literature investigating the impact of government expenditure on economic growth, more specifically defense spending, these studies have been categorized into two main branches namely defense economics (Aizenman and Glick, 2006; Dunne et al., 2005; Heo, 2010; Hou and Chen, 2013; Islam, 2015; Kuimova, 2020; Looney, 1988; Nonneman and Vanhoudt, 2011; Nusrate and Niaz, 2016; Polimeni et al., 2007; Temple, 1998; Tian et al., 2018; Tian and Lopes, 2020; Tiwari, 2010; Wezeman et al., 2020) and the mainstream government expenditure dominating public sector economics. For instance impact of government health expenditure on growth by (Kurt, 2015), Education expenditure on growth (Ainomugisha et al., 2020). These studies are discussed below.

An earlier survey of the literature on the impact of military expenditure on growth points to the fact that unlike studies that generalize these expenditures to be a cure for a security problem, (Looney, 1988) departs from this view and argues that the most decisive fact is the possibility of threat and its intensity. That is the case of Africa, the level of military expenditure depends on the government's willingness to either meet or contain people's demands. Dunne et al.,(2005)survey the state of the art theoretical and econometric methods that have dominated most of the studies on military expenditure and economic growth. Some of the most prominent frameworks on this issue include the Feder-Ram model, augmented Solow, and Barro models that link growth and military expenditure. In their review, the authors argue that the Feder-Ram framework has many pitfalls and should be avoided. That it is only suitable for defense work as opposed to public sector economics. They conclude that much as mainstream economics studies have not found concrete 
evidence for positive impacts of military spending on growth, studies in defense economics have. And thus argue in support of alternative frameworks based on both Solow augmented and Barro models for future work in this field. A closely related study by (Aizenman and Glick, 2006) makes innovation by incorporating both external threat and level of corruption as controls in the evaluation of non-linearity between military expenditure. Interestingly growth first falls in the presence of only military expenditure, however, when the possibility of external threat is accounted for, military expenditures increase growth.

According to (Hou and Chen, 2013), the debate on the real impact of military expenditure on economic growth still rages on due to the varying theoretical and estimation strategies that have been used. In their study to examine the impact of military expenditure, Hou and Chen applies a systems GMM's approach to test the Augmented Solow growth model to the dataset from 35 developing countries for the years 1975 to 2009. Their results indicated that military expenditure a decreasing significant effect on economic growth from the studied countries. These results could still be a result of the models and estimation methods adopted but it is needless to mention that even their cross-section regression also has several shortcomings. First, this estimation strategy does not utilize all available information, secondly, this estimation technique suffers from omitted variable and measurement biases. Thirdly inconsistency may also result from endogeneigty between multiple repressors. A study in the USA from 1954-2005, (Heo, 2010) applies both the Feder-Ram and Solow augmented growth models to address the estimations issues of simultaneity and multicollinearity bias common in both of these frameworks. He finds that defense spending does not significantly affect economic growth in the USA. A related study in India, by (Tiwari, 2010) extends the estimation strategy by Derger by applying the VECM time series approach. His results indicate a bi-directional relationship between economic growth measured by GDP and defense spending, but he reports uni-directional causality between other study control variables such as merchandise trade gross domestic savings.

A multi-country study by Ohiul (2015) finds varying effects of military on economic growth, his study considered 41 countries for a period of ten years (2001-2010). Besides his panel data model finds positive effects for labor and capital just like in other studies (see Hou and Chen, 2013) in this regard country-specific effects are important in the explanation of the military expenditure growth nexus. Similarly (Nusrate and Niaz, 2016) examines the causal relationships between military expenditure and growth, similar to (Aizenman and Glick, 2006), he incorporates the impact of both internal and external threat using data from 1990 to 2013 for 70 developing countries. His results point to varying and mixed results based on the estimation strategy. For instance, insignificant results are obtained in the case of cross-sectional OLS and fixed effects approach, while the impact turns out positive across other specification strategies and thus specification biases could be pinned for varying results of military expenditure on growth. In conclusion, most of the reviewed studies point to varying results of military expenditure on growth.

\section{Methodology and data sources}

\subsection{Theoretical framework}

Our modeling endeavor starts from the traditional neoclassical school of thought, which views a country as a rational agent who seeks to maximize her well-defined national interest depicted in the social welfare function by balancing its opportunity cost, and the benefits that accrue from military spending (D’Agostino et al., 2012; Dunne et al., 2005). In this setup, military expenditure is then seen as pure public good and thus its economic benefits are derived from a comparison of 
its opportunity cost and the tradeoff between civil public expenditure and military expenditure. Following this approach, a former theoretical framework is developed to inform the discussions below. To model the effects of military expenditure on economic growth in Uganda, we follow the Augmented Solow growth model first introduced by Mankiw and others in 1992 and formalized in practice by Knight and others in 1996 (see(Dunne et al., 2005) ). A major assumption is made about the share of military expenditure $(m=M / Y)$, which affects productivity of factors of production through level effects on the efficiency parameter that controls labor-augmenting technical change. Following the formulation by (Dunne et al., 2005), we start off with a traditional neoclassical production function:

$$
Y(t)=K(t)^{\beta}[A(t) L(t)]^{1-\beta}
$$

The above function incorporates, aggregate real income (Y), real capital stock (K), labor (L), and technology (A) and changes according to:

$$
A(t)=A_{0} e^{g t} m(t)^{\gamma}
$$

Other variables are still as defined above, $g$ and $m$ are technical progress and share of military expenditure in national output. In this specification, a change in $m$ has no effect on the steady-state growth rates in the long-run, but it affects per-capita income along the steady-state growth path which in return affects transitory growth rates along the same steady-state path as it approaches a new steady-state equilibrium. From the traditional assumptions of the Solow growth model, including exogenous savings $s$, constant rates of growth of labor $n$ and a specific rate of capital depreciation $\delta$, dynamically capital accumulation evolves through the equation below.

$$
\dot{k}_{e}=s k_{e}^{\beta}-(g+n+\delta) k_{e} \Leftrightarrow \frac{\partial \ln k_{e}}{\partial t}=s e^{(\beta-1) \ln k_{e}}-\left(g+n_{\delta}\right),
$$

The rate of change in capital stock with respect to effective labor is $\left(\dot{k_{e}}=k / A L\right)$, and $\beta$ is the constant capital-output elasticity. Solving the above capital dynamic path differential equation yields the steady-state level of equilibrium of capital $k_{e}$ as;

$$
\begin{gathered}
k_{e}^{*}=\left[\frac{s}{g+n_{-} \delta}\right]^{1 /(1-\beta)} \\
\frac{\partial \ln y_{e}}{\partial t}=(\beta-1)(g+n+\delta)\left[\ln y_{e}(t)-\ln y_{e}^{*}\right]
\end{gathered}
$$

From the above equation (6), we obtain the steady-state level of output per effective unit of labor

$$
y_{e}^{*}=\left[\frac{s}{g+n+\delta}\right]^{\beta /(1-\beta)}
$$

Remember in the steady-state, capital changes according to the equation below.

$$
\ln \mathrm{y}^{*}(\mathrm{t})=\ln \mathrm{y}_{\mathrm{e}}^{*}+\ln \mathrm{A}_{0}+\gamma \ln \mathrm{m}^{*}+\mathrm{gt}
$$


Just like in other growth models, the outcome variable is growth rate (GDP growth rate) as a function of investment/savings, the growth rate of labor, military expenditure is treated is captured as current/lagged values. This augmented version of the growth model is a one-sector model, it assumes only one commodity is produced. There is no direct influence of military expenditure and technology but the effect is just ad hoc, the same applies to savings to and lastly the disturbance term is also ad hoc. But several other control variables are included for completeness such as per capita GDP, education, population growth, and the investment share and threat variable is also includes combining techniques from both (Dunne et al., 2005) and (Aizenman and Glick, 2006). The exploratory power of the above model is fully discussed by (Nonneman and Vanhoudt, 2011; Temple, 1998). However, it is important to note that our major contribution to the literature is in estimation of impact of military expenditure in Uganda.

\subsection{Data source and variable Description}

This study uses data from (1970-2018) majorly from three sources, namely the Bank of Uganda (BoU), the World Banks's compiled World Development Indicators (WDI), and the Stockholm International Peace Research Institute (SIPRI). These sources provide a host of very informative information on the key macroeconomic variables as discussed in table 1 below. Data on military expenditure from SIPRI is derived from the definition of NATO, which constitutes defense expenditure on both current and capital spending on the armed forces, defense ministries, other security-related MDAs, peace missions abroad, and other military installations and spaces. SIPRI sources this military expenditure data from different national governments, it is derived from budget documents and defense white paper and other official government documents such as the national statistical abstract from UBOS, Country reports from both the IMF and the World Bank. Growth information from the World Bank is preferred to the local sources due to numerous missing data points that create several inconsistencies in the local data sources. The large sample considered and length of the series proposed neutralizes the missing values problem in the data set. Study variables' definitions, measurements, and their respective sources are discussed in table 1 below.

\section{Table 1 Definition of variables and sources of data}

\begin{tabular}{|c|c|c|c|}
\hline Variable name & Symbol & $\begin{array}{l}\text { Definition/measurement } \\
\text { Growth variables }\end{array}$ & Source \\
\hline $\begin{array}{l}\text { Economic growth } \\
\text { (GDP-growth) }\end{array}$ & Growth & Percentages increase in GDP per year & $\begin{array}{l}\text { World Bank (WDI)/ } \\
\text { Bank of Uganda }\end{array}$ \\
\hline Capital & $\mathrm{K}$ & $\begin{array}{l}\text { This is the real gross fixed capital } \\
\text { formation ( } \% \text { of GDP) }\end{array}$ & World Bank (WDI) \\
\hline Labor & $\mathrm{L}$ & Labor is the labor force in Uganda & World Bank (WDI) \\
\hline Trade Openness & TO & $\begin{array}{l}\text { This study used the sum of exports and } \\
\text { imports to GDP ratio as a proxy for } \\
\text { trade openness }\end{array}$ & World Bank (WDI) \\
\hline $\begin{array}{l}\text { Population growth } \\
\text { rate }\end{array}$ & (Pop_r) & $\begin{array}{l}\text { The rate at which the number of people } \\
\text { increases as the proportion of the total } \\
\text { population in a given period }\end{array}$ & World Bank (WDI) \\
\hline Real Interest Rates & (Rir) & $\begin{array}{l}\text { This is defined as lending interest rate } \\
\text { adjusted for inflation as measured by } \\
\text { the GDP deflator }\end{array}$ & World Bank (WDI) \\
\hline Inflation & Inf & $\begin{array}{l}\text { The fraction of increase in price in the } \\
\text { country ( } \% \text { increase in prices) } \\
\text { Security variables }\end{array}$ & World Bank (WDI) \\
\hline
\end{tabular}




\begin{tabular}{|c|c|c|c|}
\hline Military expenditure & Milex & $\begin{array}{l}\text { Measured as a percentage of GDP spent } \\
\text { on defense }\end{array}$ & $\begin{array}{l}\text { SIPIR/ World Bank } \\
\text { (WDI }\end{array}$ \\
\hline $\begin{array}{l}\text { Military expenditure } \\
\text { of neighbor (TZ) }\end{array}$ & Milex_Nei & $\begin{array}{l}\text { Measured as a percentage of GDP spent } \\
\text { on defense }\end{array}$ & $\begin{array}{l}\text { SIPIR/ World Bank } \\
\text { (WDI }\end{array}$ \\
\hline Conflicts & $\mathrm{C}$ & $\begin{array}{l}\text { Whether a country experienced any of } \\
\text { type of conflicts (major, minor, internal } \\
\& \text { external), yes }=1, \text { No }=0\end{array}$ & $\begin{array}{l}\text { UCDP - Uppsala } \\
\text { Conflict Data } \\
\text { Program }\end{array}$ \\
\hline Election year & Ey & $\begin{array}{l}\text { This is a binary capturing a given year } \\
\text { as an election year }(\mathrm{yes}=1) \text { or not } \\
(\mathrm{No}=1) \text {. }\end{array}$ & $\begin{array}{l}\text { GoU/ Election } \\
\text { Commission }\end{array}$ \\
\hline Regime type & RT & $\begin{array}{l}\text { This is the type of political dispensation } \\
\text { practiced in the country, in Uganda it } \\
\text { has been either } 1=\text { multiparty, } 2=\text { Single } \\
\text { party state }\end{array}$ & World Bank (WDI) \\
\hline
\end{tabular}

Note: variables defined according to World Bank WDI compilations

Source: Authors' own compilation

\subsubsection{Pre-estimation tests}

Given the fact that we are modeling military expenditure effects using time series estimation techniques, it is imperative to carry out some statistical tests to test the suitability of the data towards time-series assumptions (i.e., causality test). Among these tests are the unit root test and Co-integration test. According to Gujarati (1995), a series must be tested for Stationarity using the unit root test to avoid spurious results. To him, a series is said to be stationary if it exhibits constant measures of central tendency that is the mean and variance not changing over time, where the value of covariance only depends on the length of the period between any two given points but not on actual variation. To test for stationary in the study series we adopt the commonly used Augmented Dickey-Fuller (ADF) test for unit root. On the other hand, we assumed that there is theoretical support for the cointegration relationship because time series variables exhibit cointegration if separate times share a common stochastic trend. In this case, the idea of the shared trend in this study variables is supported by economic growth theories adopted. Following this framework, it implies that growth factors considered in table 1 are all cointegrated. To test for this assumption, we adopt the 1990 Johansen and Juselius's (JJ) test of cointegration. These methods are said to be more superior to other techniques because it provides two likelihood ratio test statistics namely the trace value and the maximum eigenvalue number denoted as ( $\lambda$ trace) $(\lambda \max )$ respectively. The first test statistics tests the null hypothesis of $r$ cointegrating relationships versus $\mathrm{k}$. while the maximum eigenvalue method, test the null that there are $\mathrm{r}$ cointegrating vectors against $\mathrm{r}+1$. In this case, $J J$ provides critical values against which comparisons are made. The decision criteria are that if the critical value is greater than the test statistic, then we fail to reject the null of $r$ cointegrating vectors and take the alternative. It should be noted that failing to properly model cointegration in time series analysis can cause biases in the results.

\section{Empirical Model for estimation}

To model the effects of military expenditure on economic growth, we follow the Augmented Solow growth model first introduced by Mankiw and others in 1992 and formalized in practice by Knight and others in 1996 (see(Dunne et al., 2005) ). By adopting formalizations by (Aizenman and Glick, 2006; Dunne et al., 2005) of Growth versus Military expenditure nexus on equation 
(11), Growth (\% GDP) relates to military expenditure and other control variables through equation (12) below.

$$
\text { Growth }_{t}=f\left(L, K, \text { Pop }_{r}, \text { TO, Rir, Inf, Milex, Milex }{ }_{\mathrm{Nei}}, \mathrm{C}, \mathrm{Ey}, \mathrm{RT}\right)
$$

Equation (11) can be operationalized by both growth variables (capital, labor, population growth, trade openness, real interest, and inflation) and security variables (Military expenditure of home country and neighbor, conflicts, an election year and regime type), to examine the impact of military expenditure on economic growth, other variables are treated as control variables in this analysis which leads to the equation (13) below to be estimated. Following our results from the ADF test for unit root, a dynamic regression or ARDL Model is estimated to model the impacts of military expenditure on growth. The advantage of the dynamic model is that it follows dynamic specifications and requires no economic assumptions in advance for estimation (Koutun, A., 2013). Having established that study series are none cointegrated, the growth model following the Autoregressive Distributed Lag model below is estimated as ARDL (p q).

$$
\begin{aligned}
\text { Growth }_{t}= & \beta_{0}+\beta_{1} \text { Growth }_{t-1}+\beta_{2} \text { Milex }_{t-1}+\beta_{3} \text { MilNei }_{t-1}+\beta_{4} \text { TO }_{t-1}+\beta_{5} \text { Inf }_{t-1} \\
& +\beta_{6} \text { Rir }_{t-1}+\beta_{7} \text { Popr }_{t-1}+\beta_{8} L_{t-1}+\beta_{9} K_{t-1}+\beta_{10} C_{t-1}+\beta_{11} E y_{t-1} \\
& +\beta_{12} R T_{t-1}+\sum_{I=1}^{q} \delta_{1} \Delta \text { Growt }_{t-1}+\sum_{I=1}^{q} \delta_{2} \Delta \text { Milex }_{t-1}+\sum_{I=1}^{q} \delta_{3} \Delta \text { MilNei }_{t-1} \\
& +\sum_{I=1}^{q} \delta_{4} \Delta T O_{t-1}+\sum_{I=0}^{q} \delta_{5} \Delta I n f_{t-1}+\sum_{I=1}^{q} \delta_{6} \Delta \text { Rir }_{t-1}+\sum_{I=1}^{q} \delta_{7} \Delta \text { Popr }_{t-1} \\
& +\sum_{I=1}^{q} \delta_{8} \Delta L_{t-1}+\sum_{I=1}^{q} \delta_{9} \Delta K_{t-1}+\varepsilon_{t}
\end{aligned}
$$

From the above regression model, the variables for the short-run are still as defined before, in the long-run, we only estimate the effects of continuous variables on growth since it can be difficult to difference binary responses. The first part of the equation estimates short-run impacts while the second part with summations estimates impacts in the long run. Continuous variables are taken in terms of percentages while conflict, election years, and regime type are binary. The parameters of interest are majorly the $\beta$, and $\delta$, which are the short and long-run coefficients, $\varepsilon$ and $t$ are the disturbance terms and time respective, while $p$ and $q$ are lags for endogenous and exogenous variables respectively. The model is estimated using STATA version 16 and optimal lag is determined through final prediction error (FPE) and Akaike information criterion (AIC). These criteria are preferred because they are superior in the case of small samples of about 60 observations and below which is the case here. Also, these criteria minimize underestimation while increasing the chance of recovering the true lag length.

\section{Empirical estimation and results 5.1 Descriptive statistics}

In table 2 we summarize the major variables of interest that are for continuous variables (Growth, Milex, MilNei, K, L, TO, Rir, Inf, and Popr) summary statistics of means, standard deviations, 
minimum and maximum values are contributed. While for binary (Conflict, an election year, and Regime type) variables we mainly compute for frequencies and proportions. Several noted features can be derived from table 2 below:

Table 2. Descriptive Summary statistics of the variables.

\begin{tabular}{lrrrrr}
\hline \multicolumn{1}{c}{ Variable } & \multicolumn{1}{c}{ Obs } & \multicolumn{1}{c}{ Mean } & \multicolumn{1}{c}{ SD } & \multicolumn{1}{c}{ Min } & \multicolumn{1}{c}{ Max } \\
\hline GDP growth & 49 & 4.293333 & 4.417997 & -12.5 & 11.52324 \\
Milex & 49 & 2.267297 & 0.66233 & 1.162701 & 4.062172 \\
Pop growth & 49 & 3.16121 & 0.283827 & 2.553508 & 3.749875 \\
inflation & 49 & 6.171251 & 2.949042 & -0.28751 & 15.12515 \\
Real interest rate & 49 & 2.221 & 19.38907 & -53.4443 & 22.99559 \\
labor force & 49 & 71.41771 & 0.248816 & 70.889 & 72.036 \\
Trade openness & 49 & 36.74541 & 10.00589 & 21.13484 & 55.73063 \\
Capital & 49 & 16.21812 & 6.95925 & 5.608315 & 27.93457 \\
Milex TZ & 49 & 2.75244 & 2.193923 & 0.708332 & 10.10911 \\
Milex Rwanda & 49 & 2.270178 & 1.197287 & 0.607803 & 5.509172 \\
Election year & 49 & 0.142857 & 0.353553 & 0 & 1 \\
Conflict type & 49 & 1.244898 & 0.434483 & 1 & 2 \\
Conflict years & 49 & 0.612245 & 0.492288 & 0 & 1 \\
\hline
\end{tabular}

Source: Author's computation; Note: Except for (Election year, conflict type, and conflict years), all other variables are expressed in percentage form

Descriptive results above, indicate that Uganda has gravitated around an average of 4 to 5 percentage points of levels of growth for the last 5 decades. We see that Uganda has on average been spending a fraction of $2.27 \%$ of its GDP on financing military/defense expenditure. Uganda's military expenditure as a percentage of GDP has been in the same range with that of its neighbors for example that of Tanzania and Rwanda of 2.7 and 2.3 respectively for period under study. Given the fact we are analyzing trends in the study, such close military expenditure futures can be explained by the volatile relationships that existed between Uganda and Tanzania in the late 1970s during the dictatorship governments of Iddi Amin and other earlier governments. Turning to security variables we see that for the study period 1970-2019, Uganda has held elections only $14 \%$ of the time had conflict 24\% for the period under study, in fact Uganda has been preoccupied with conflicts. These findings are collaborated by (Ali and Donald, 2020) who analyzed government spending priorities in Uganda.

Table 3: Unit Root Test Statistic results for Stationarity (Augmented Dickey-Fuller, ADF test)

\begin{tabular}{|c|c|c|c|c|}
\hline \multirow[b]{2}{*}{ Variable } & \multicolumn{2}{|c|}{ Stationarity Levels } & \multicolumn{2}{|c|}{ (first differences) } \\
\hline & No trend & With draft & with trend & Status \\
\hline GDP growth & $-6.300 * * *$ & & & $\mathrm{I}(0)$ \\
\hline Milex & $-5.269 * * *$ & & & $\mathrm{I}(0)$ \\
\hline Pop growth & $-5.878 * * *$ & & & $\mathrm{I}(0)$ \\
\hline inflation & $-5.203 * * *$ & & & $\mathrm{I}(0)$ \\
\hline Real interest rate & $-5.144 * * *$ & & & $\mathrm{I}(1)$ \\
\hline labor force & & $-3.042 * *$ & & $\mathrm{I}(0)$ \\
\hline Trade openness & $-3.684^{*}$ & & & $\mathrm{I}(0)$ \\
\hline Milex TZ & $-6.853 * *$ & & $-7.648 * *$ & $\mathrm{I}(1)$ \\
\hline
\end{tabular}




\begin{tabular}{|c|c|c|c|c|}
\hline Capital Formation & & & $-4.401 * * *$ & $\mathrm{I}(1)$ \\
\hline Milex Rwanda & & & $-6.214 * *$ & $\mathrm{I}(1)$ \\
\hline Conflict years & & $-4.796 * * *$ & & $\mathrm{I}(1)$ \\
\hline Election year (EY) & $-7.507 * * *$ & & & $\mathrm{I}(0)$ \\
\hline Conflict Type & & & $-4.007 * * *$ & $\mathrm{I}(1)$ \\
\hline
\end{tabular}

Note: All variables are in first difference except for inflation: $p$ values of coefficients: $* * * p<$ $0.01, * * p<0.05$ and $* p<0.1$

From the above ADF test result results for unit root, after the first difference of study sequences, we find that the absolute values for the test statistic of all variables tested are far beyond greater than $1 \%, 5 \%$, and $10 \%$ of the critical values to the left of the distribution. Therefore we now reject the Null hypothesis and accept the alternative that the first difference (except for inflation) of the percentage growth in the study variables are stationary and thus this implies the null of the presence of unit root is rejected in favor of the alternative of no unit root test. Since our sequence variables become stationary at the first difference, meaning being integrated of order one I(1), it is important that we perform a cointegration test to establish whether the series exhibit a long-run relationship. In this case, we assume the existence of a long-run relationship in the model even though the series may be drifting apart or trending upwards or downwards. Using the Johansen Cointegration test the hypotheses to be tested are $\left(\mathrm{H}_{0}\right.$ : there is no cointegration equation versus $\mathrm{H}_{1}$ : Ho is not true). Lastly, it is imperative to note that this test is performed on the level form variables, not the first difference variables. The rejection criteria are at a 5\% level of significance. As noted in section 4.1 the Jahansen test gives two results (the Trace and Max values), we thus reject the null if Trace and Max statistics are greater than 5\% critical value, otherwise, we fail to reject the null hypothesis.

Table 3 Results from the Johansen Cointegration test

\begin{tabular}{lrrrr}
\hline & \multicolumn{2}{c}{ Trace test } & \multicolumn{2}{c}{ Max test } \\
\cline { 2 - 5 } Maximum rank & Trace statistics & Critical value (5\%) & Max Statistics & Critical value (5\%) \\
\hline 0 & 429.3495 & 233.13 & 115.2282 & 62.81 \\
1 & 314.1214 & 192.89 & 87.9872 & 57.12 \\
2 & 226.1342 & 156 & 68.1843 & 51.42 \\
3 & 157.9499 & 124.24 & 58.244 & 45.28 \\
4 & 99.7059 & 94.15 & 39.486 & 39.37 \\
5 & $60.2199 *$ & 68.52 & $23.8891 *$ & 33.46 \\
6 & 36.3308 & 47.21 & 21.2108 & 27.07 \\
7 & 15.12 & 29.68 & 10.372 & 20.97 \\
8 & 4.748 & 15.41 & 4.304 & 14.07 \\
9 & 0.444 & 3.76 & 0.444 & 3.76 \\
\hline
\end{tabular}

Source: Author's computation

Under the Jahansen test of cointegration, the most important statistics to focus on are the trace and Max statistics with their respective critical values at a 5\% level of significance. In this test, we reject the null of no cointegration if trace and max statistics are greater than their respective critical values at a 5\% level of significance. The maximum rank denotes the presence and the number of cointegration equations and also represents the respective hypotheses. From table 3 above, from maximum rank 0 to 5 , we see that trace and max statistics are greater than their respective critical values implying that there exist 0 to 5 cointegration equations in each case. On the other hand, since both the trace and max statistics are lower than respective critical values for maximum ranks 
from (6 to 9) then we fail to reject the null hypothesis and agree that in this set of models we have the maximum rank of 6 to 9 cointegration equations. Finally, given the results from trace and max tests then we collectively reject the null hypothesis of no cointegration equation in this model. In this, we are fortunate that the trace result and max result agree in this model. We thus proceed to estimate the impact of military expenditure (\% of GDP spent on the defense budget) on economic growth (as \% increase in GDP) in Uganda in the short run based on the Autoregressive Distributive Lag model (ARDL). The advantage of using the ARDL estimation framework, in this case, is that it is more efficient when you have relatively small and finite sample sizes. Also, by applying the ARDL model we are posed to obtain unbiased long-run estimates in this case.

Table 4 ARDL estimation results for the effects of public debt on economic growth

\begin{tabular}{|c|c|c|c|c|}
\hline Variables & Coef. & SD & $\mathbf{t}$ & $\mathbf{P}>\mathbf{t}$ \\
\hline GDP growth (L1) & 0.0187172 & 0.2140694 & 0.09 & 0.931 \\
\hline Milex & -0.3012393 & 1.726204 & -0.17 & 0.864 \\
\hline Milex (L1) & -2.81413 & 1.833933 & -1.53 & 0.146 \\
\hline Pop growth & -35.47093 & 32.90924 & -1.08 & 0.298 \\
\hline Pop growth (L1) & 119.7231 & 92.26177 & 1.3 & 0.214 \\
\hline Pop growth (L2) & -209.3412 & 121.5858 & -1.72 & 0.106 \\
\hline Pop growth (L3) & $187.1081 *$ & 88.91977 & 2.1 & 0.050 \\
\hline Pop growth (L4) & $-64.77781 * *$ & 30.435 & -2.13 & 0.05 \\
\hline inflation & 0.1303927 & 0.197896 & 0.66 & 0.52 \\
\hline Milex TZ & -0.0158715 & 0.6254022 & -0.03 & 0.98 \\
\hline Milex TZ (L1) & -0.1531431 & 0.5781194 & -0.26 & 0.795 \\
\hline Milex Rwanda & 0.0650341 & 0.6742319 & 0.1 & 0.924 \\
\hline Milex Rwanda (L1) & $0.9269797 *$ & 0.5189941 & 1.79 & 0.044 \\
\hline Real interest rate & -0.0720698 & 0.0722575 & -1 & 0.334 \\
\hline Real interest rate (L1) & -0.0363468 & 0.0480434 & -0.76 & 0.461 \\
\hline Real interest rate (L2) & 0.0579273 & 0.0615723 & 0.94 & 0.362 \\
\hline Labor force & 0.8803937 & 0.9450476 & 0.93 & 0.366 \\
\hline Labor force (L1) & $-2.740389 * * *$ & 1.198342 & -2.29 & 0.037 \\
\hline Labor force (L2) & $-3.31838 *$ & 1.088755 & -3.05 & 0.008 \\
\hline Labor force (L3) & 1.330099 & 1.462522 & 0.91 & 0.377 \\
\hline Labor force (L4) & $3.707237 * *$ & 1.572896 & 2.36 & 0.032 \\
\hline Trade Openness & 0.0675031 & 0.0326229 & 2.07 & 0.056 \\
\hline Trade Openness (L1) & 0.0432087 & 0.0262848 & 1.64 & 0.121 \\
\hline Trade Openness (L2) & 0.0268601 & 0.0451996 & 0.59 & 0.561 \\
\hline Election Year & 1.106742 & 1.303466 & 0.85 & 0.409 \\
\hline Capital formation & -0.1095003 & 0.4260022 & -0.26 & 0.801 \\
\hline Capital formation (L1) & -0.2349323 & 0.3045946 & -0.77 & 0.453 \\
\hline Capital formation (L2) & 0.3786428 & 0.277222 & 1.37 & 0.192 \\
\hline Conflict type & -2.324977 & 2.354735 & -0.99 & 0.339 \\
\hline Cons & 30.83806 & 93.8045 & 0.33 & 0.747 \\
\hline Number of obs & & & & 45 \\
\hline $\mathrm{F}(29, \quad 15)$ & & & & 6.06 \\
\hline R-squared & & & & 0.9214 \\
\hline Adj R-squared & & & & 0.7693 \\
\hline Prob $>$ F & & & & 0.0003 \\
\hline
\end{tabular}


Notes: coefficients show association between dependent and independent variables.

\section{Stability test}

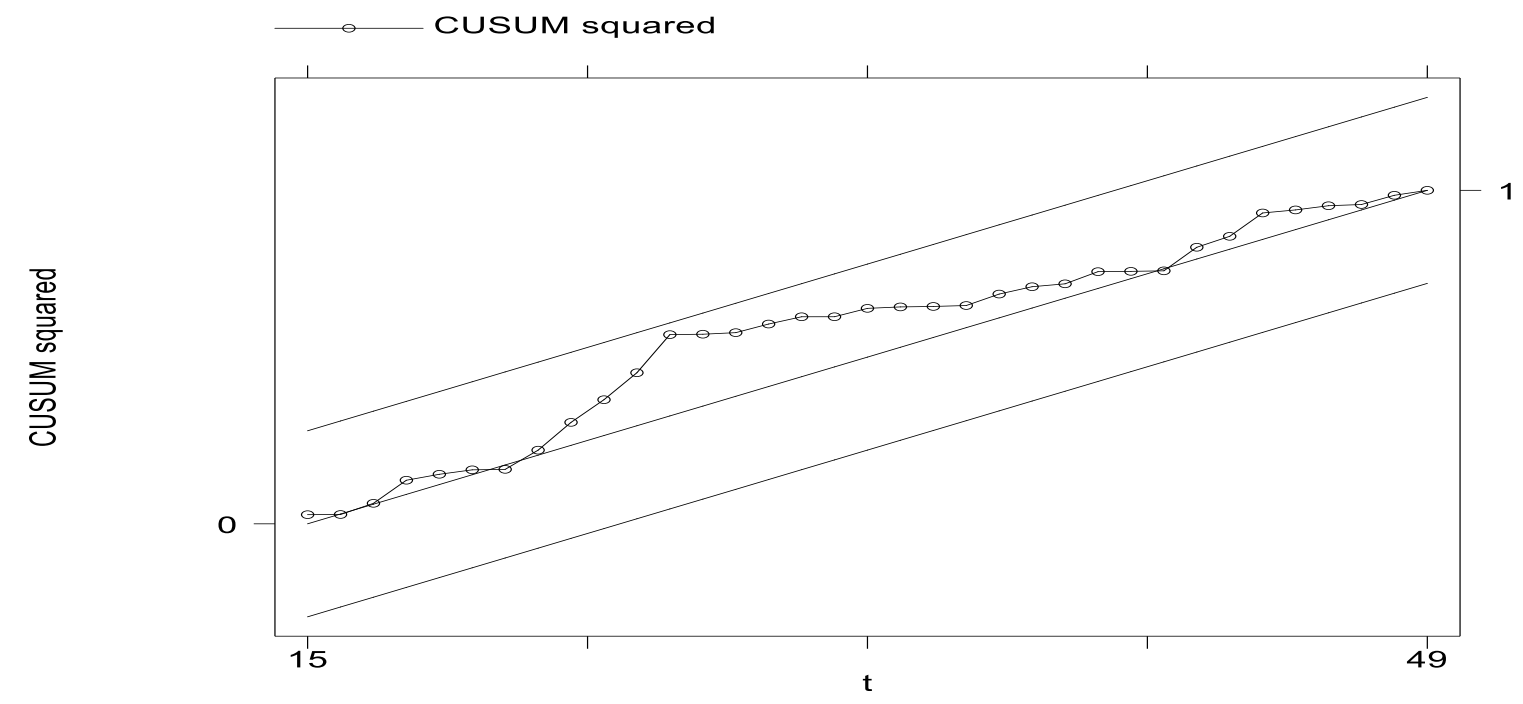

Figure 1: test for Stability of the ARDL model

To examine the stability of the model, we call on the famous cumulative summations' plot (Cusum) in Fig. 1 above, since the Cusum curve above is bound between 5\% of the distribution in the short run over the study period, then we conclude that the estimated ARDL model is stable and it satisfies, most of the principal elements of econometric diagnostic tests to be fit for estimation. This result is supported by additional diagnostic tests reported in section 6. Looking at the model significance from the above simple model, with an F of 6.06 and R-square of 0.9214 , this is indicative that the variables included in the model collectively explain over $92 \%$ of the variation observed in the growth rates in the model. Tables 4 and 5 present a simple model, short and longrun effects of each of the study variables on economic growth rates in Uganda

\section{Discussion of results}

It is important to note that in the case of the ARDL model, the interpretations of the short-run coefficients are taken as simply ceteris-peribus effects, and therefore influence, in this case, can be based on the usual OLS standard errors and t-statistics. For the long-run relationship between the variables, the t-statistics on the coefficients of the lagged error correction term indicates that there is Granger-causality in the association.

Thus from table 4 above, we see that a one percent change in the first lag of GDP growth is associated with a $0.018 \%$ increase in the GDP on average ceteris peribus at a $5 \%$ level of significance. On the other hand, a percentage point change in the level and first lag of military expenditure (Milex) is associated with 0.30 and 2.81 percentage point reduction in GDP growth in Uganda. A similar result is found in (Islam, 2015; Saba and Ngepah, 2019). Although the impact of military expenditure on the economy has been uncertain depending on the role of the expenditure, for instance, according to (D'Agostino et al., 2012) military expenditure can be 
growth-enhancing if it meets to create a peaceful environment for businesses to thrive but it can be detrimental if such expenditure is to finance external wars and internal conflicts, where productive resources like labor and capital are lost. Turning to the impact of population on economic growth, it's not suppressing that a 1 percentage point rise in the population in Uganda is associated with 35.47 percentage point's reduction in economic growth and the same applies to the three of the four lags applied in this study ceteris peribus at 1 and 5\% level of significance. As the main component of the financial markets, see that a 1 percentage point increase in general price levels (inflation) is associated with a 0.13 percentage point increase in economic growth, this result may be centrally to the economic theory. However, this scenario can be occur if the increase in the money in circulation is accompanied by increased production, this increase in production can then lead to raise in economic growth amidst inflation raise.

Turning on the security variables of the model, we see that military expenditure on the neighbor i.e., Tanzania and Rwanda, has an impact on economic growth in Uganda, for instance, a 1 percentage point rise in military expenditure in Tanzania and Rwanda is associated with 0.015 and 0.06 percentage points reduction in GDP growth in Uganda in case of Tanzania, while is increases growth in Uganda in case of Rwanda. The explanation of this scenario is two folds, first for Tanzania Uganda has in the past had conflicts with Tanzania particularly in the 1970s, "the battle of Kageera", thus implies that during these periods, a rise in military expenditure led to a reduction in Uganda's growth because most resources from diverted from productive purposes to national security issues. Secondly, it is a different story for Rwanda, there have been confrontational conflicts been these countries and thus military expenditure in Rwanda may not have any impact on the country's growth, except in the recently isolated incidences. Turning to other control variables that may influence the impact of the military on growth, we see that controlling for election years leads to 1.11 percentage points raise in GDP growth while the type of conflict on which defense budget is spent is associated with a 2.32 percentage point reduction in economic growth. Conversely, a one percentage point rise in real interest is associated with $0.072,0.04$, and 0.06 reduction in economic growth respectively. Trade openness also features significantly, a one percentage point change in trade openness is associated with a $0.07,0.04$, and 0.03 increase in GDP growth rate. Finally, labor force participation and capital formation are also associated with a rise in GDP growth, for instance, a one percentage point rise in labor force participation is associated with $0.88,1.33$, and 3.70 percentage point increase in GDP growth rates for level, third and fourth lags, while a reduction is observed in the first and second lags respectively, and the effect is significant at 1 and 5\% level. For capital formation, a positive association is observed in the second lag at 0.38 percentage points.

Table 5 Diagnostics tests on ARDL Model

\begin{tabular}{llll}
\hline Test for & Tests & Critical values & Decision \\
\hline Serial correlation & Durbin-Watson & $=2.836351$ & No serial correlation \\
Heteroscedasticity & White's test & Prob $>$ chi $2=0.4298$ & No Heteroscedasticity \\
Normality & Jarque-Bera Test & $.9869 \quad$ Chi $(2)=0.6105$ & Normal residuals \\
Goodness of fit & Likelihood ratio test & 0.8819 & Good fit \\
\hline
\end{tabular}

Source: Author's computation from study data.

From the above diagnostic results, it can be seen that the model does not suffer from serial correction, this is because the Durbin-Watson d-statistic is 2.836, indicating no serial correction. 
Whites' test for Ho: Homoscedasticity against Ha: unrestricted Heteroscedasticity, with a Prob > chi2 $=0.4298$, which is not significant, this implies that we fail to reject the null hypothesis and conclude that the model is homoscedastic. On the other hand, with Jarque-Bera Chi (2) statistics of 0.6105 , we cannot reject the null and thus conclude that the model is normal.

Table 5 Summary of the error correction model results (short-run)

\begin{tabular}{|c|c|c|}
\hline Variable & Short Run & Long Run \\
\hline $\boldsymbol{A D J}$ GDP growth (L1) & $-0.9812828(0.2140694)$ & \\
\hline Milex (D1) & $2.81413(1.833933)$ & $-3.174792(2.706868)$ \\
\hline \multicolumn{3}{|l|}{ Pop growth } \\
\hline Pop growth (D1) & $-32.7122(28.91769)$ & $-2.811337(7.179619)$ \\
\hline Pop growth (LD) & 87.0109 (64.70689) & \\
\hline Pop growth (L2D) & $-122.33 *(60.94559)$ & \\
\hline Pop growth (L3D) & $64.77781 * *(30.435)$ & \\
\hline Milex TZ (D1) & $0.153143(0.578119)$ & $-0.1722384(0.6990465)$ \\
\hline Inflation & & $0.1328798(0.1964667)$ \\
\hline Milex Rwanda (D1) & $-0.92698 * * *(0.518994)$ & $1.010936(0.8036219)$ \\
\hline Real interest rate (D1) & $-0.02158(0.063156)$ & $-0.0514523(0.0746982)$ \\
\hline Real interest rate (LD. & $-0.05793(0.061572)$ & \\
\hline Labor force (D1) & $1.021433(1.521315)$ & $-0.1437295(1.461156)$ \\
\hline Labor force (LD) & $-1.71896(1.31423)$ & \\
\hline Labor force (L2D) & $-5.03734 *(1.41066)$ & \\
\hline Labor force (L3D) & $-3.70724 * *(1.572896)$ & \\
\hline Trade Openness (D1) & $-0.07007(0.057158)$ & $0.1401959(0.0928038)$ \\
\hline Trade Openness (LD) & $-0.02686(0.0452)$ & \\
\hline Capital formation (D1) & $-0.14371(0.333992)$ & $0.0348628(0.3341918)$ \\
\hline Capital formation (LD) & $-0.37864(0.277222)$ & \\
\hline Election year (EY) & & 1.127853 (1.401608) \\
\hline Conflict Type (C) & & $-2.369324(2.279621)$ \\
\hline cons & & $30.83806(93.8045)$ \\
\hline Number of obs & & 45 \\
\hline R-squared & & 0.8819 \\
\hline Adj R-squared & & 0.6537 \\
\hline Root MSE & & 2.141 \\
\hline Log-likelihood & & -73.390571 \\
\hline
\end{tabular}

Note: tables 5 shows coefficients and Standard errors in the Parenthesis

From table 5 above see that the adjustment coefficient $(A D J)$ is negative as expected, this is crucial for long run convergence among study variables and this also indicates that previous periods' errors were well corrected in the current period and thus in this model the speed of adjustment was 98.12\% (ADJ=-0.9812). It is important to note that we use variables in their percentage format to reduce the variance and reduce the problem of outliers and biased estimates.

\section{Conclusion and Policy direction.}

The motivation of this study was to examine the impact of military/defense expenditure in Uganda for the period 1970-2019, including times of political turmoil in Uganda and those periods that the 
country has witnessed relative peace and stable leaves of growth. The study applies a time-series estimation strategy, specifically the ARDL model to yearly data of selected growth and securityrelated variables for both the short and long-run scenarios given the fact our sequences were integrated into two orders. The analysis showed that military/defense expenditure is negatively associated with economic growth (growth of GDP) while it is positively associated with growth in the long run. Other growth variables have mixed effects on economic growth, for instance, population shows, labor force growth, real interest rates negative impacts in both scenarios, while capital formation and inflation are negatively associated with growth in the short run and positively associated in the long run. The picture is not different for security variables either, for example, military expenditure of neighbor (Tanzania and Rwanda), and election year all indicate negative association and a positive association in short and long run respective. Having this view on the finding of this study, particularly on military/defense expenditure, numerous policy directions are proposed.

The most fruitful implication of this study is that the persistent increase in military expenditure versus other productive sectors must be discouraged particularly if the country is not facing any military threats from anyone. Military expenditure as a form of government public expenditure has implications that extend beyond the number of resources that are allocated to it, specifically when such spending leads to deaths due to confrontation conflicts. Whereas governments are mandated to ensure some level of security to protect their people and resources from both internal and external attacks, according to D'Agostino et al., (2012) this is associated with some opportunity cost, this is because military expenditure diverts resources from more productive investment sectors like health, education, and agriculture which may even speed up the pace economic development. Such factors play a crucial role in the development of low-income countries like Uganda. Given the fact the most of the defense budgets in most of the low-income countries like Uganda are top security secret normally referred to classified budget, it is even difficult to trace the economic impacts of such monies, notwithstanding corruption tendencies which ravage defense ministries of such countries. Besides Uganda does not manufacture any armies used by the armed forces apart from a few incidences of gun assembling, this means most procurements of defense equipment involving sending Uganda's meager resources abroad to countries like China, the UK, and the USA to purchase fire armies. This is detrimental to the economy as it will adversely affect the investment environment due to capital flight. Therefore government should ensure that military spending is commensurate with other productive sectors that have the potential to unlock Uganda's growth trajectory.

Turning to population, Uganda is home to the youngest population not only on the African content but also globally, $70-80 \%$ to be specific of the population are below 30 years, thus government can harness the power of this population dividend and at the same population control measures sure be vigorously employed. This can be done through investing more in their productive skills as indicated by the impact of capital formation on economic growth. Also, the government should ensure job creation to absorb most of the labor among the country's resourceful youths. On the issue of security variables, Uganda should stop acting the big brother role in Uganda, because this attracts external threats, a case in point is the bombing in 2011, secondly, election year indicates positive effects on growth due to two main resources, first increased importation of firearms to control demonstrations and scare off potential competition, secondly increased monetization of politics in Uganda at all levels of the electro process means during election season there is a lot of money in the circulation. Given this state government should take a deliberate stand to monetization of the politics in Uganda. We thus conclude that the optimistic results obtained in 
this study are entirely dependent upon the political will and direction of the Ugandan government and its people for their achievement.

Acknowledgments: Extend my sincere appreciation to the Coordinator of the Ph.D. in Economics program at the School of Economics at Makerere University who also doubles as my lecturer for the Public sector course and my advisor on the paper for his invaluable advice. Secondly am highly grateful to my colleague from the Ph.D. for Economic class of 2018/19 who provided technical review input and advice on the modeling techniques.

Authors' contributions: MJ is the main author of this article; he booted the idea of the topic to be researched, he also carried out a rigorous literature review to establish gaps in case of military expenditure regarding Uganda. Thirdly he collected data from different sources and analyzed it based on the developed theoretical framework. JBO \& JW coauthored this manuscript, he provided invaluable advice and approved the research idea, and proofread the work, and also ensured quality assurance at all stages of the Manuscript.

Authors' information: MJ is an Assistant lecturer at the school of statistics at Makerere University, and he is also currently a Ph.D. student at the School of Economics (SoE) at the same University. JBO is a senior lecturer at the School of Economics (SoE) at Makerere University, at the school of economics (SoE) at the College of Business and Management Sciences (CoBAMS) and WJ is a senior lecturer and Dean at the school of statistics at Makerere University.

Source of funding: The study did not receive any funding from anywhere.

Availability of data and materials: All the data (1970-2019) used in the study were sourced from mainly three specific sources. Data on Economic growth came from World Bank accessed at https: //data.worldbank.org/country/uganda?view and bank of Uganda accessed at https: //www.bou.or.ug/bou/rates statistics /statistics .html. Data on the military expenditure of both Uganda and the neighbors, type and frequency of conflict came from SIPRI accessed at https://www.sipri.org/databases/milex, other variables on inflation, labor force participation, trade openness, and capital formation was sourced from the World Bank Development Indicators (WDI). Most importantly all the datasets utilized in this study's analysis are available from the corresponding author.

Competing interests: The authors declare that they have no competing interest in this publication.

Author details: Makerere University School of Public Health, Kampala, Uganda.

\section{References}

Ainomugisha, P., Turyareeba, D., Mbabazize, R.N., Katutsi, V., Atwine, A., 2020. Employment-Growth Nexus within the East African States. Mod. Econ. 11, 1836-1857.

https://doi.org/10.4236/me.2020.1111124

Aizenman, J., Glick, R., 2006. Military expenditure, threats, and growth. J. Int. Trade Econ. Dev. 15, 129-155. https://doi.org/10.1080/09638190600689095

Ali, H.E., Donald, O.M., 2020. Global Encyclopedia of Public Administration, Public Policy, and Governance. Glob. Encycl. Public Adm. Public Policy, Gov. 1-6. https://doi.org/10.1007/978-3319-31816-5

Ali, H.E., Omong, D.M., 2020. Global Encyclopedia of Public Administration, Public Policy, and Governance. Glob. Encycl. Public Adm. Public Policy, Gov. https://doi.org/10.1007/978-3-31931816-5

Bove, V., Brauner, J., 2016. The demand for military expenditure in authoritarian regimes. Def. Peace Econ. 27, 609-625. https://doi.org/10.1080/10242694.2014.925325

D’Agostino, G., Dunne, J.P., Pieroni, L., 2012. Assessing the Effects of Military Expenditures on Growth, The Oxford Handbook of the Economics of Peace and Conflict. https://doi.org/10.1093/oxfordhb/9780195392777.013.0017

Dignum, F., Davidsson, P., Hurk, M. Vander, Kammler, C., Ludescher, L.G., Mellema, R., Vanhee, L., Dignum, V., Ghorbani, A., Jensen, M., Lorig, F., Melchior, A., Pastrav, C., Verhagen, H., 2020. Analyzing the combined health, social and economic impacts of the coronavirus pandemic using 
agent-based social simulation. arXiv 177-194.

Dunne, J.P., Smith, R.P., Willenbockel, D., 2005. Models of military expenditure and growth: A critical review. Def. Peace Econ. 16, 449-461. https://doi.org/10.1080/10242690500167791

Heo, U., 2010. The relationship between defense spending and economic growth in the united states. Polit. Res. Q. 63, 760-770. https://doi.org/10.1177/1065912909334427

Hou, N., Chen, B., 2013. Military expenditure and economic growth in developing countries: Evidence from system gmm estimates. Def. Peace Econ. 24, 183-193. https://doi.org/10.1080/10242694.2012.710813

Islam, M.O., 2015. The Relation between Military Expenditure \& Economic Growth in Developing Countries: Evidence from a Panel of 41 Developing Countries. IOSR J. Econ. Financ. Ver. I 6, 2321-5933. https://doi.org/10.9790/5933-06415765

Koutun, A., K.P., 2013. An Empirical Study of the Solow Growth Model 1-62.

Kuimova, A., 2020. Understanding Egyptian Military Expenditure 25.

Kurt, S., 2015. Government health expenditures and economic growth: A feder-ram approach for the case of Turkey. Int. J. Econ. Financ. Issues 5, 441-447.

Looney, R.E., 1988. Military Expenditures and Socio-Economic Development in Africa: A Summary of Recent Empirical Research. J. Mod. Afr. Stud. 26, 319-325. https://doi.org/10.1017/S0022278X00010491

Nonneman, W., Vanhoudt, P., 2011. A Further Augmentation of the Solow Model and the Empirics of Economic Growth for OECD Countries Author ( s ): Walter Nonneman and Patrick Vanhoudt Source : The Quarterly Journal of Economics, Vol . 111, No. 3 ( Aug ., 1996 ), pp. 943-953 Published by. Q. J. Econ. 111, 943-953.

NPA, 2020. Third National Development Plan (NDPIII) 2020/21-2024/25. Natl. Plan. Auth.

Nusrate, M., Niaz, M., 2016. www.econstor.eu.

Omitoogun, W., 2003. Military Expenditure Data in Africa. A Survey of Cameroon, Ethiopia, Ghana, Kenya, Nigeria, and Uganda. Stockholm.

Polimeni, J., Iorgulescu Polimeni, R., Trees, W., 2007. Extending The Augmented Solow Growth Model To Explain Transitional Economies. J. Econ. Forecast. 4, 65-76.

Saba, C.S., Ngepah, N., 2019. Military expenditure and economic growth: evidence from a heterogeneous panel of African countries. Econ. Res. Istraz. 32, 3586-3606. https://doi.org/10.1080/1331677X.2019.1674179

Temple, J.R.. ., 1998. Robustness Tests of the Augmented Solow Model Author ( s ): Jonathan R . W . Temple Published by Wiley Stable URL : https://www.jstor.org/stable/223186 13, 361-375.

Tian, N., Lopes, D., 2020. Military Spending and Official Development Assistance in the Recipient States : Is There a Relationship ? 2002, 18-22.

Tian, N., Wezeman, P., Yun, Y., 2018. Military Expenditure Transparency in Sub-Saharan Africa. Sipri policy Pap. 48.

Tiwari, A.K., 2010. Defense Expenditure and Economic Growth : Evidence from India Abstract: J. Cambridge Stud. 5, 117-131.

Uganda Bureau of Statistics (UBOS), 2017. Manpower Survey Uganda 2016/2017.

Wezeman, P.D., Béraud-sudreau, L., Sipri, S.T.W., 2020. TRANSPARENCY IN ARMS PROCUREMENT : LIMITATIONS AND OPPORTUNITIES FOR ASSESSING GLOBAL ARMAMENT DEVELOPMENTS.

Wijeweera, A., Webb, M.J., 2012. Using the Feder-Ram and military Keynesian models to examine the link between defense spending and economic growth in Sri Lanka. Def. Peace Econ. 23, 303-311. https://doi.org/10.1080/10242694.2011.593352 